\title{
CHANGES IN THE CORPORATE GOVERNANCE AND OWNERSHIP STRUCTURE IN STOCK MARKETS: DEMUTUALIZATION OF ISTANBUL STOCK EXCHANGE
}

\author{
Serra Eren Sarıoğlu ${ }^{1}$
}

\begin{abstract}
Stock exchanges around the world have experienced major changes with respect to corporate governance beginning with the early 1990s. Until that time, almost all exchanges were member-owned, organized as "non-profit" mutual organizations. Although there were no publicly traded exchanges 15 years ago, today most of the stock exchanges are demutualized and many of them are public listed companies. In this paper, the concept of demutualization is presented with some historical evolution of this process. The forces that might affect the stock exchanges are pointed out and the problems in the process of demutualization are emphasized. Besides, the key issues for consideration of the demutualization of Istanbul Stock Exchange (ISE) are discussed in detail, and the impacts of demutualization to the capital markets of Turkey are extensively revealed in this paper. In the light of the evidence provided by the prior studies examining the effects of demutualization to the stock exchanges and the advantages of a successful process, demutualization of ISE is recommended in this study. The successful act of demutualization of ISE will result in many benefits to the Turkish Economy.
\end{abstract}

Keywords: Demutualization of stock exchanges, Istanbul Stock Exchange, emerging stock markets

JEL Codes: G01, G2, G30

\section{Introduction}

Starting in the early 1990s, stock exchanges around the world have been experiencing major changes with respect to corporate governance. Although there were no publicly traded exchanges fifteen years ago, today 23 stock exchanges are public listed companies. Besides, 12 stock exchanges are not listed but demutualized. The development and, in some instances the survival of many stock exchanges are being threatened by the pressures of competition, globalization and technological changes. This led to tremendous strains in the governance and decision making of stock exchanges.

This paper briefly presents the concept and historical evolution of the demutualization of stock exchanges. The forces driving the demutualization and the problems faced in this process are also explained in the paper. Besides, for the demutualization of Istanbul Stock Exchange (ISE) in particular, the key issues for consideration are discussed in detail. Furthermore, this study tries to extensively reveal the impacts of demutualization to the capital markets of Turkey.

The contribution of this paper to the finance literature is to shed a light on the subject of the demutualization of an emerging stock exchange market-Turkey and to reflect some considerations about the pros and cons of the process of demutualization to Turkish Financial System.

The remainder of this paper is organized as follows: The next section gives a brief history of the demutualization of the stock exchanges. Forces driving the demutualization of stock exchanges, the problems in the process of demutualization and the performances of the stock exchanges after demutualization are also explained in this second section. Following section provides information

\footnotetext{
${ }^{1}$ Istanbul University, School of Business, Turkey, e-mail: serraeren@istanbul.edu.tr
} 
about Turkish Financial Sector and ISE. This is followed by the fourth section giving information about the demutualization of ISE. Concluding remarks form the last part of the paper.

\section{Demutualization of Stock Exchanges}

Demutualization is defined as the process of reorganizing a member-owned, non-profit mutualized entity into a for-profit corporation with shareholders. In this section, the history of demutualization will be explained in regards of stock exchanges. Besides the forces driving the stock exchanges to demutualize, benefits and costs of demutualization and the problems in the process of demutualization will be emphasized. Lastly, by the help of the light shed by some empirical studies, the performances of the stock exchanges after demutualization will be examined.

\section{History of the Demutualization of the Stock Exchanges}

Since the beginning of 1990s several stock exchanges have become for-profit companies, opened ownership to outside investors rather than just members and introduced their companies' shares on the stock market they operate. Before then, most of the exchanges around the world were non-profit organizations owned by their members. The ownership and membership of an exchange were bundled together until the early 1990s. The natural organization form for early exchanges was a membership club with exclusive privileges to trade in specific geographic locations (Aggarwal and Dahiya, 2005: 6).

In the process of 'demutualization', stock exchanges change their institutional settings towards profit-oriented corporations. The first stock exchange demutualized was Stockholm Stock Exchange and the trend of demutualization started in 1993 with this demutualization. As of August 2012, twenty-three member stock and derivative exchanges of World Federation Exchange (WFE) were publicly listed corporations. Table 1 clearly shows that almost all member exchanges have demutualized and listed their shares.

Table no.1.

Legal Status of the Member Stock Exchanges of WFE

\begin{tabular}{|l|c|c|}
\hline \multicolumn{1}{|c|}{ Stock Exchange } & Legal Status & $\begin{array}{c}\text { Year of } \\
\text { Demutualization }\end{array}$ \\
\hline Athens Stock Exchange & Public listed company & 1999 \\
\hline Australian Securities Exchange & Public listed company & 1998 \\
\hline BM\&FBOVESPA S.A. & Public listed company & 2007 \\
\hline BME Spanish Exchanges & Public listed company & 2001 \\
\hline Bolsa de Comercio de Santiago & Public listed company & NA \\
\hline Bolsa de Valores de Colombia & Public listed company & 2001 \\
\hline Bolsa de Valores de Lima & Public listed company & NA \\
\hline Bolsa Mexicana de Valores & Public listed company & NA \\
\hline Bursa Malaysia & Public listed company & 2004 \\
\hline CBOE Holdings, Inc. & Public listed company & 2006 \\
\hline CME Group & Public listed company & 2002 \\
\hline Deutsche Börse & Public listed company & 2000 \\
\hline Hong Kong Exchanges and Clearing & Public listed company & 2000 \\
\hline Jasdaq Securities Exchange (Osaka Stock & Public listed company & 2001 \\
Exchange) & & \\
\hline Johannesburg Stock Exchange & Public listed company & 2005 \\
\hline London Stock Exchange Group & Public listed company & 2000 \\
\hline NASDAQ OMX Group & Public listed company & 2008 \\
\hline NYSE Euronext & Public listed company & 2007 \\
\hline OMX Group & Public listed company & 1993 \\
\hline Philippines Stock Exchange & Public listed company & 2001 \\
\hline Singapore Stock Exchange & Public listed company & 1999 \\
\hline TSX Group & Public listed company & 2000 \\
\hline
\end{tabular}




\begin{tabular}{|l|c|c|}
\hline Warsaw Stock Exchange & Public listed company & 2010 \\
\hline $\begin{array}{l}\text { Bucharest Stock Exchange (affiliated member } \\
\text { of WFE) }\end{array}$ & Public listed company & 2010 \\
\hline Bermuda Stock Exchange & Demutualized but not listed & 1992 \\
\hline Bombay Stock Exchange & Demutualized but not listed & 2005 \\
\hline $\begin{array}{l}\text { Budapest Stock Exchange (CEE Stock } \\
\text { Exchange Group) }\end{array}$ & Demutualized but not listed & 2002 \\
\hline Korea Exchange & Demutualized but not listed & 2005 \\
\hline Malta Stock Exchange & Demutualized but not listed & 2007 \\
\hline National Stock Exchange of India & Demutualized but not listed & 1993 \\
\hline Oslo Bors & Demutualized but not listed & 2001 \\
\hline SIX Swiss Exchange & Demutualized but not listed & 2002 \\
\hline Stock Exchange of Mauritius & Demutualized but not listed & 2008 \\
\hline Stock Exchange of Tehran & Demutualized but not listed & 2006 \\
\hline Taiwan Stock Exchange & Demutualized but not listed & 1961 \\
\hline Tokyo Stock Exchange Group Inc. & Demutualized but not listed & 2001 \\
\hline Bourse de Casablanca & Private limited company & - \\
\hline Bourse de Luxemburg & Private limited company & - \\
\hline Indonesia Stock Exchange & Private limited company & - \\
\hline Irish Stock Exchange & Private limited company & - \\
\hline Tel Aviv Stock Exchange & Private limited company & - \\
\hline $\begin{array}{l}\text { Wiener Börse AG (CEE Stock Exchange } \\
\text { Group) }\end{array}$ & Private limited company & - \\
\hline Bolsa de Comercio de Buenos Aires & Association & - \\
\hline Shanghai Stock Exchange & Association & - \\
\hline Shenzhen Stock Exchange & Association & - \\
\hline Amman Stock Exchange & Other legal status & - \\
\hline Colombo Stock Exchange & Other legal status & - \\
\hline Cyprus Stock Exchange & Other legal status & - \\
\hline Istanbul Stock Exchange & Other legal status status & - \\
\hline Moskow Interbank Currency Exchange & - \\
\hline Saudi Stock Exchange (Tadawul) & & - \\
\hline Stock Exchange of Thailand & & \\
\hline The Egyptian Exchange & Status & \\
\hline Source: World Federation of Exchanges & & - \\
\hline
\end{tabular}

After the stock exchange of Stockholm, Helsinki Stock Exchange has demutualized in 1995. It was followed by several others, including the Copenhagen Exchange in 1996, the Amsterdam and Italian Exchange in 1997, the Australian Exchange in 1998, Hong Kong, Deutsche Börse, Euronext and London Stock Exchange in 2000. The TSX Group owns the Toronto Stock Exchange that demutualized in 2000 and went public in 2002.

The NASDAQ Stock Market was the first stock exchange that demutualized in the U.S in the year 2000 and the shares of NASDAQ started trading on the Over-the-Counter Bulletin Board in 2002. Chicago Merchantile Exchange (CME) has demutualized in 2002 and conducted an initial public offering in 2003 and listed on the New York Stock Exchange (NYSE) (Aggarwal and Dahiya, 2005: 5). Table 1 also displays the years the stock exchanges have demutualized. Although most major European and North American stock exchanges have demutualized including initial public offering, major Asian stock exchanges are rather unwilling to go public (Nu Ri, 2011: 307).

The process of demutualization takes place in stages and can take many different forms. In the first stage, the members become the legal owners of the corporation as given shares in. In this first stage, some corporations can also raise capital through a private placement. In the second stage, demutualized exchange can either stay private or can list its own shares and remove all restrictions 
on trading. The examples of publicly listed and demutualized but not listed exchanges are given as a full list in Table 1. A demutualized exchange can also become a subsidiary of another publicly traded exchange. For example, the Helsinki Stock Exchange became a subsidiary of the OM Group in 2003.

Demutualization of stock exchanges has frequently led to consolidation among stock exchanges not only within the area they operate in but also across the borders in order to become more competitive (Nu Ri, 2011: 307). For example, Paris, Brussels, Amsterdam, Lisbon and LIFFE stock exchanges have combined to form Euronext Group and Euronext merged with NYSE. After then, this group has acquired AMEX. OMX Group is formed by Stockholm, Copenhagen, Vilnius, Iceland, Helsinki, Tallinn and Riga stock exchanges and acquired by NASDAQ in 2008. This was followed by the mergers between the stock exchanges and futures exchanges in Canada and Brazil in May 2008; and the link-up between the Chicago Merchantile Exchange and NYMEX futures markets. Lately, on February 2011, NYSE Euronext and Deutsche Börse confirmed they would merge to become the world's largest trading platform.

\section{Forces Driving the Demutualization of Stock Exchanges}

The changes in the traditional organization structures of the stock exchanges are being driven mainly by three forces: (1) increased global competition, (2) technology and the rise of "Electronic Communication Networks (ECNs)" and (3) growing conflicts of interest between existing owners (Aggarwal, 2002: 107). Heightened competition among the financial exchanges at the regional and global level has been one of the major factors in the decisions of exchanges to demutualize. Stock exchanges are no longer monopolies in their region and they must be managed to increase efficiency and profits. Besides, the growing threat from alternative trading systems has put some pressure on exchanges to adopt more efficient trading systems and to migrate to electronic trading. As markets have become more sophisticated, the interests of various member groups began to diverge. This led to tremendous strains in the governance and decision making of stock exchanges (Aggarwal and Dahiya, 2005: 8).

\section{Problems in the Process of Demutualization}

Although it is believed that demutualization brings various benefits to the stock exchanges, there exist lots of problems in the process of demutualization. Each stock exchange tried to solve these problems in their unique models. The first problem stock exchanges face is to determine the structure of the exchange after demutualization. What will be the sources of income of the newly established exchange and what will be the targeted services? For example, Deutsche Börse has located itself as a technology company. Data dissemination and progression of technology are the main services of Deutsche Börse alongside operating the money and capital markets. Contrarily, London Stock Exchange has declared its business description as operating only the common stock market. The second crucial problem is the determination of the owners of the demutualized exchange. Although the exchanges are the organizations that have established and operated by the members, they have social responsibilities like being an intermediary in distributing the public savings efficiently. This social responsibility reveals the discussions about the ownership of the exchanges.

The third problem is the management of the exchange. In the case of stock exchanges, the management is determined different than an ordinary corporation. The groups that are affected by the operations of the exchanges are also having rights in the management of the exchanges in the manner of public interest. The fourth problem is the listing of the stock exchanges. Exchanges can choose to go public in order to meet their financing needs or to share their income with public. The stock exchange that has listed its shares in its own market has also some problems in determining the auditing of the conditions of quotation. Each demutualized stock exchange has solved these problems by constituting a unique model that is suitable with the country's conditions and regulations. 


\section{Performances of the Stock Exchanges after Demutualization}

The academicians have conducted empirical studies in order to find out the benefits of demutualization to the stock exchanges. The data about the subject is insufficient as the trend of demutualization is very recent. Therefore, the literature about the performance analysis is very scarce and the impact of demutualization on the market performances of stock exchanges is not clear yet.

In a study conducted by O'Hara and Mendiola (2003), the financial performances of the demutualized and listed stock exchanges have been investigated. The stock exchanges were Singapore, Athens, Deutsche Börse, Euronext, Australian, Hong Kong, London and NASDAQ. The financial performance was divided into four components: Accounting-based, return-based, riskbased and the comparison of the exchange with the economic variables. They have calculated the return on asset, return on equity, operating margin, asset turnover and financial leverage of the exchanges before and after the demutualization process. According to the findings of this study, the demutualization did not seem to increase the performance of the exchanges in regards of accounting-based measures. However, in the means of return-based measures, the returns of demutualized exchanges were greater than their market indices. A similar study was realized by Aggarwal and Dahiya (2005). They have computed fewer variables than O'hara and Mendiola (2003) and found out conflicting results for the investigated exchanges. They have emphasized that much more time and data is needed in order to get significant results.

Krishnamurti, Sequeira and Fangjian (2003) have compared two stock exchanges operating in India with different corporate governance structures. Bombay Stock Exchange (BSE) was a nonprofit cooperation at those times, while National Stock Exchange (NSE) was a demutualized exchange. Both exchanges had similar operating systems. By using "Hasbrouck's measure of market quality", the researchers found out that NSE is better than BSE by means of corporate governance. Morsy and Rwegasira (2010) have investigated the performances of 26 stock exchanges by using eleven financial ratios for the period 1996-2004. Only the four ratios were significantly found to be improved after the demutualization. In a study conducted by Senbet and Gande (2009), stock exchanges of 63 countries (some mutual and some demutualized) were chosen to evaluate the impacts of 2008 global financial crisis. The researchers applied econometric analysis for the average figures of the exchanges without making any discrimination about the corporate governance structures.

\section{Istanbul Stock Exchange}

\section{Turkish Financial Sector}

Financial markets of developing countries are mainly different from the developed economies' financial markets in the means of their characteristics and operations. One of the main reasons of these differences is that developing markets do not have that much long histories like developed markets. Government intervention in these markets is very intense because the governments are trying to build up and enhance the financial infrastructure in these economies. Besides, the difficulties existing in their economic structures like high inflation and interest rates, budget deficits, and unemployment issues bring lots of problems to the financial markets of developing countries. Lastly, the financial markets of emerging economies are usually inefficient because of insufficient regulation systems, weak regulatory authorities, problems arising from the high interest rates and short terms in credit markets, and the absence of financial deepening.

In January 1980, Turkish Government decided to implement a step-by-step liberalization program by announcing a comprehensive stabilization and structural adjustment package. The aim of the new economic package was to create an export-oriented and liberalized economy which is competitive in the world markets. Price and exchange rate controls, trade reforms, determination of interest rates by market forces to encourage private savings, adoption of special policies with generous incentives to attract Foreign Direct Investment, and privatization of State-Owned 
Enterprises were some of the components of the program. By these reforms and incentives, Turkey has opened its markets broadly and deeply.

Main objectives of the liberalization of Turkish Financial System were to increase competition, service quality, technology, investment in human capital and asset-liability management. The major steps taken were: Establishment of government securities and interbank markets, introduction of open market operations with government securities, introduction of Capital Market Board, and re-opening of Istanbul Stock Exchange. (Mercan et.al, 2003: 188). Also, a new set of regulations facilitated a broader range of institutions to provide financial services. Investment banks, securities firms, mutual funds, insurance and finance companies are some of the examples. In the mean time, technological advances and financial innovation increased the service quality of the financial intermediaries. The Turkish Financial Sector grew rapidly as a result of these structural changes. However, domestic and global risks of the country increased as well. As a result, Turkey experienced many economic crises: The emergence of the Gulf War was followed by the crisis of 1991. Despite the large fiscal deficit and high inflation, an attempt to fix the interest rates led to another crisis in 1994. The Far East crisis in 1997 and the Russian crisis in 1998 had strong contagion effects on Turkish Economy. The earthquakes of August and November 1999 had also shaken the economic and financial system of the country. Despite the supervision of IMF, the economy was shattered with a banking crisis in November 2000 and a currency crisis in February 2001 (Ozmucur, 2007: 763).

Turkey was hit hard by the Global Financial Crisis in 2008 and 2009. GDP fell by 4.8 percent in 2009. But with the beginning of the second quarter of 2009, the economy was already growing again. GDP grew by 8.9 percent in 2010 and 8.5 percent in 2011 (see Table 2). However this rapid growth led to a widening current account deficit. While inflation was under control, unemployment remained relatively high (Table 2).

Table no.2.

Selected Macroeconomic Indicators of Turkey

\begin{tabular}{lccccccc}
\hline & $\mathbf{2 0 0 5}$ & $\mathbf{2 0 0 6}$ & $\mathbf{2 0 0 7}$ & $\mathbf{2 0 0 8}$ & $\mathbf{2 0 0 9}$ & $\mathbf{2 0 1 0}$ & $\mathbf{2 0 1 1}$ \\
\hline GDP growth rate (\%) $_{\text {Inflation rate }}^{\mathrm{a}}$ & 8.4 & 6.9 & 4.7 & 0.7 & -4.8 & 8.9 & 8.5 \\
Unemployment rate & 8.2 & 9.6 & 8.8 & 10.4 & 6.3 & 8.6 & 6.0 \\
Current account balance/GDP & 10.6 & 10.2 & 10.2 & 10.9 & 14.0 & 12.0 & 10.5 \\
Total investment/GDP & -4.6 & -6.0 & -5.9 & -5.7 & -2.3 & -6.6 & -10.2 \\
\hline
\end{tabular}

Source: IMF International Financial Statistics

${ }^{\mathrm{a}} \mathrm{Change}$ in average consumer price

The feature of Turkish financial system is very similar to the other developing countries' systems: Few numbers of financial institutions with small sizes. However, it has an above the average size compared to that of the emerging markets. The chronicle inflation lasting for years and low level of savings are some of the reasons of this weak financial system. The government securities have dominated the capital markets for several years. As can be seen from Table 3, in 2010 public bonds and bills to GDP ratio is 32 per cent, while private bonds and bills to GDP is only 1 per cent. The distinctive feature of the Turkish capital markets is that the majority share in the sector belongs to the banking system (see Table 3). While the bank asset to GDP ratio is 91 per cent, capital markets ratio is only 75 per cent. However, there has been an increase in the number and size of non-bank financial institutions in the last years. As it is known, the growth and deepening of the financial system is affected by the growth and strengthening of non-bank financial institutions. 
Table no.3.

Selected Indicators of Financial Sector to GDP Ratios

\begin{tabular}{|c|c|c|c|c|c|c|c|c|c|c|c|c|}
\hline & \multicolumn{3}{|c|}{2001} & \multicolumn{3}{|c|}{2008} & \multicolumn{3}{|c|}{2009} & \multicolumn{3}{|c|}{2010} \\
\hline & World & $\mathbf{E M}^{\mathbf{a}}$ & $\mathbf{T R}^{\mathrm{b}}$ & World & EM & TR & World & EM & TR & World & EM & TR \\
\hline Bank assets & 256 & 140 & 69 & 160 & 87 & 75 & 159 & 89 & 87 & 159 & 89 & 91 \\
\hline $\begin{array}{l}\text { Capital } \\
\text { markets }\end{array}$ & 228 & 60 & 80 & 192 & 79 & 47 & 241 & 98 & 71 & 238 & 99 & 75 \\
\hline Equities & 93 & 27 & 28 & 55 & 42 & 19 & 82 & 55 & 37 & 88 & 58 & 43 \\
\hline Bonds\& bills & 135 & 33 & 51 & 137 & 38 & 28 & 159 & 42 & 35 & 151 & 41 & 32 \\
\hline Public & 71 & 21 & 51 & 52 & 23 & 28 & 63 & 27 & 35 & 66 & 26 & 32 \\
\hline Private & 63 & 11 & 0 & 85 & 15 & 0 & 96 & 15 & 0 & 85 & 16 & 1 \\
\hline Total & 484 & 199 & 149 & 352 & 167 & 121 & 400 & 186 & 159 & 397 & 189 & 166 \\
\hline
\end{tabular}

Source: IMF Global Financial Stability Report, September 2011

${ }^{a}$ EM: Emerging countries

${ }^{\mathrm{b}} \mathrm{TR}$ : Turkey

\section{Evolution and Structure of Istanbul Stock Exchange}

With its roots dating back to the $19^{\text {th }}$ century, ISE was established in 1986 as a public corporation operating as an autonomous and professional institution. ISE is a public legal entity which independently uses the powers under its own responsibility and is supervised and monitored by the Capital Markets Board. ISE is entitled to issue legal regulations related to the subjects and fields within the scope of its authority. The General Assembly comprising of the ISE Members is the supreme decision making body. A board of directors composed of seven members, one person being chairman and six persons being members, acts at Securities Exchange. Chairman of Exchange and three members are appointed with joint decree upon proposal by the Minister to whom Capital Markets Board relates. The remaining three members of Board of Directors are elected amongst the members by the general assembly meetings. The internal regulations of ISE are prepared by the Executive Council, decided upon by the General Assembly and become effective with the approval of Capital Markets Board in accordance with the following provision of the Decree Law No.91, "Rules on trading transactions on the securities exchange are determined with a regulation by the Executive Council of the Exchange" (Report on Markets and Operations, 2010: 8).

ISE is the member of The World Federation of Exchanges (WFE), Federation of Euro-Asian Stock Exchanges (FEAS) and Federation of European Securities Exchanges (FESE). ISE has the shareholding interests in ISE Settlement and Custody Bank, Central Registry Agency and Turkish Derivatives Exchange. Within the scope of international efforts aimed at developing and supporting the capital markets and equity exchanges of the region, it has also shareholdings in Kyrgyz, Baku and Sarajevo stock exchanges.

\section{ISE by Figures}

Being a fundamental part of the Turkish Capital Markets, vision of ISE includes contributing to the Turkish Economy by operating as a dependable, transparent, stable and fair market in line with efficiency and competitive principles. ISE is providing an environment for the trading of a wide variety of securities, namely, stocks, government bonds, treasury bills, money market instruments, corporate bonds, foreign securities and exchange traded funds. There are four main markets operating at the ISE: Stock Market, Bonds and Bills Market, Emerging Companies Market and Foreign Securities Market. Stock Market and Bonds and Bills Market are the two important markets of ISE by means of market capitalization and trade value. In Table 4, the main stock market indicators of ISE can be found for the period 1986-2011.

In the first year of its operation, the market capitalization of ISE was only 938 million USD. In 2011 this figure was recorded as 201,924 million USD. The market capitalization of the exchange has grown 215 times in the passing 25 years. But the impacts of the financial crises can easily be investigated from Table 4. Gulf War Crisis has caused the market capitalization of ISE to decrease from 15,564 million USD to 9,922 million USD in 1992. The ratio of market capitalization 
to GDP has fallen from 9.32 per cent to 5.77 per cent. Similarly, the crises of 1994, 1998 and 2001 have affected the market capitalization of the exchange. Before the Global Financial Crisis in 2008, the market capitalization of ISE was 289,986 million USD and the ratio of this figure to GDP was 39.84 per cent. In 2009 the market capitalization has fallen to 119.698 million USD and the ratio to GDP to 19.15 per cent.

Table no. 4.

Main Indicators of ISE Stock Market (1986-2011)

\begin{tabular}{|c|c|c|c|c|c|}
\hline Year & $\begin{array}{c}\text { Market } \\
\text { Capitalization } \\
\text { (Million USD) }\end{array}$ & $\begin{array}{c}\text { Market } \\
\text { Cap./GDP } \\
\text { (per cent) }\end{array}$ & $\begin{array}{l}\text { Traded Value } \\
\text { (Million USD) }\end{array}$ & $\begin{array}{c}\text { Traded } \\
\text { Value/GDP } \\
\text { (per cent) }\end{array}$ & $\begin{array}{c}\text { Number of } \\
\text { Companies } \\
\text { Listed }\end{array}$ \\
\hline 1986 & 938 & 1.03 & 13 & 0.01 & 80 \\
\hline 1987 & 3,125 & 3.17 & 118 & 0.10 & 82 \\
\hline 1988 & 1,128 & 1.18 & 115 & 0.09 & 79 \\
\hline 1989 & 6,756 & 5.09 & 773 & 0.57 & 76 \\
\hline 1990 & 18,737 & 10.45 & 5,854 & 2.90 & 110 \\
\hline 1991 & 15,564 & 9.32 & 8,502 & 4.20 & 134 \\
\hline 1992 & 9,922 & 5.77 & 8,567 & 3.84 & 145 \\
\hline 1993 & 37,824 & 20.51 & 21,770 & 9.60 & 160 \\
\hline 1994 & 21,785 & 16.08 & 23,203 & 12.53 & 176 \\
\hline 1995 & 20,782 & 12.12 & 52,357 & 22.76 & 205 \\
\hline 1996 & 30,797 & 16.49 & 37,737 & 15.31 & 228 \\
\hline 1997 & 61,879 & 32.65 & 58,104 & 23.92 & 258 \\
\hline 1998 & 33,975 & 15.12 & 70,396 & 25.78 & 277 \\
\hline 1999 & 114,271 & 58.45 & 84,034 & 35.28 & 285 \\
\hline 2000 & 69,507 & 28.02 & 181,934 & 66.81 & 315 \\
\hline 2001 & 47,689 & 28.56 & 80,400 & 38.76 & 310 \\
\hline 2002 & 34,402 & 16.08 & 70,756 & 30.33 & 288 \\
\hline 2003 & 69,003 & 21.13 & 100,165 & 32.25 & 285 \\
\hline 2004 & 98,073 & 23.71 & 147,755 & 37.28 & 297 \\
\hline 2005 & 162,814 & 33.64 & 201,763 & 41.60 & 304 \\
\hline 2006 & 163,775 & 30.33 & 229,642 & 42.74 & 316 \\
\hline 2007 & 289,986 & 39.84 & 300,842 & 45.99 & 319 \\
\hline 2008 & 119,698 & 19.15 & 261,274 & 34.99 & 317 \\
\hline 2009 & 235,996 & 36.82 & 316,326 & 49.82 & 315 \\
\hline 2010 & 307,551 & 42.76 & 425,747 & 57.52 & 331 \\
\hline 2011 & 201,924 & 25.75 & 423,584 & 54.26 & 361 \\
\hline
\end{tabular}

Source: $w w w . i s e . o r g$

Figure 1 is prepared to compare the market capitalization to GDP ratio of ISE with the member countries of OECD. Although the market capitalization of ISE has gained acceleration in the last 25 years, it is still very low compared to OECD countries. In year 2011 market capitalization to GDP ratio of ISE was 29.75 per cent while ratio of OECD countries was 66.30 per cent. 


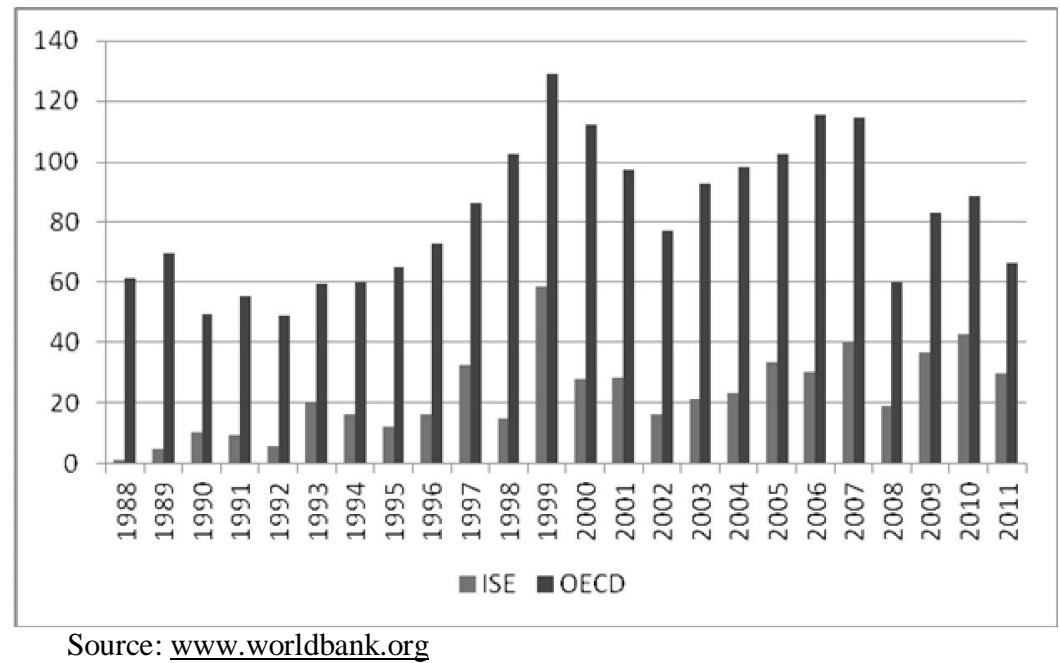

Figure no.1. - ISE and OECD Countries Stock Market Capitalization/GDP

ISE has started its operations in 1986 with 80 companies. Currently, stocks of 361 companies are being traded in the markets of exchange (Table 4). In the first years of ISE, the number of companies listed was increasing very fast, but after then it has slowed down. Istanbul Chamber of Industry publishes every year the list of 500 largest companies of Turkey. Amongst them, only the stocks of 105 companies are traded in ISE. The Capital Markets Board of Turkey, the Union of Chambers and Commodity Exchanges of Turkey, ISE and the Association of Capital Market Intermediary Institutions of Turkey signed a cooperation protocol to initiate an Initial Public Offering (IPO) Campaign in August 2008 in order to allow companies to benefit from the opportunities offered by the capital markets. In this regard, ISE made amendments in its regulations so as to allow the trading of companies with more than 250 shareholders, without having to go through a new public offering process, provided that they are registered with the Capital Markets Board. There is a potential of over 200 companies that can be traded on the ISE Stock Market in this context. The number and volume of IPOs are given in Figure 2.

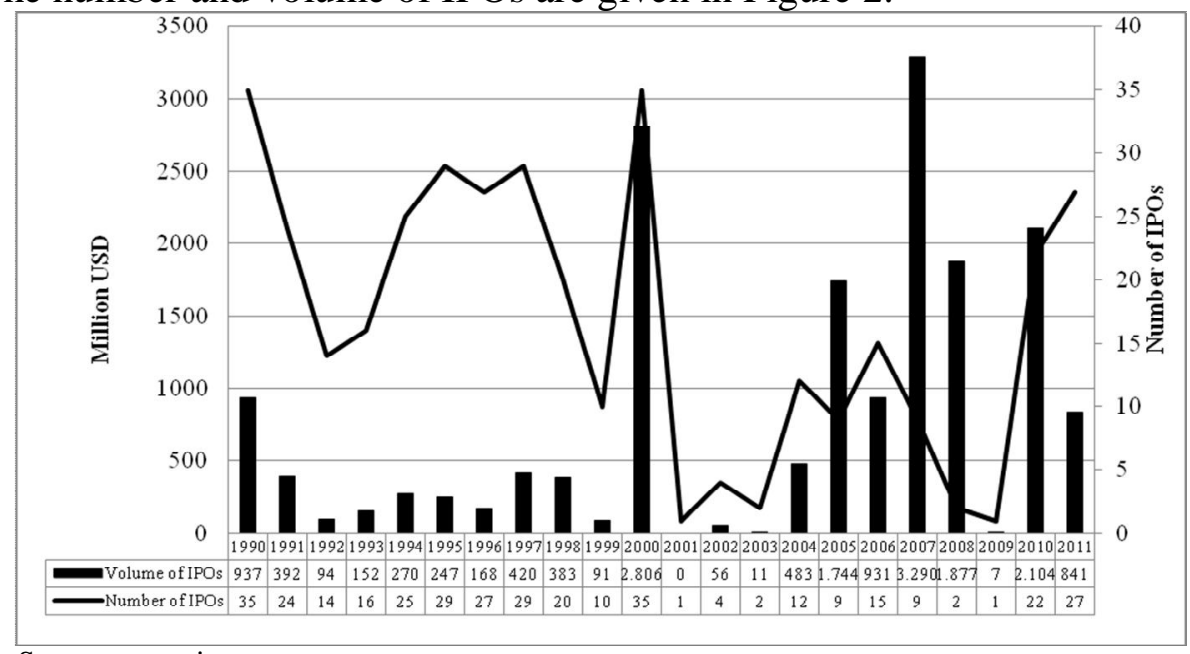

Source: www.ise.org

Figure no. 2. Volume and Number of IPOs in ISE

The efforts carried out within the framework of 'IPO Campaign' led the annual number of initial public offerings to increase from an average of 9 during the 2000-2009 period to 27 in 2011. This was the best performance in terms of IPO since 2000 . 
The interest of foreign investors to emerging markets has increased till the end of 2007 (72 per cent). The Global Financial Crisis has affected the purchasing of the foreigners in these markets. In 2008 the share of the foreigners has fallen to 67 per cent and currently foreigners own the 62 per cent of the common stocks in the exchange.

Bonds and Bills Market of ISE was established in 1991, five years after the Stock Market establishment. Government bonds and Treasury bills traded in this market are the securities issued by the public sector. Private sector issues private sector bonds, bank bills, asset-backed securities and commercial papers. These securities are traded at Outright Purchases and Sales Market, Repo/Reverse Repo Market, Interbank Repo/Reverse Repo Market, Repo Market for Specified Securities and Offerings Market for Qualified Investors. The breakdown of the trading value for 2011 was as follows: 70.41 per cent in Repo/Reverse Repo Market, 11.60 per cent in the Outright Purchases and Sales Market, 17.78 per cent in the Interbank Repo/Reverse Repo Market. In Table 5 traded values in Bonds and Bills Market are given for the period 1997-2011. As the other markets shares are very low, the traded values in these markets are not given in the table.

Table no.5.

Traded Values in ISE Bonds and Bills Market (1997-2011) (Million USD)

\begin{tabular}{|c|c|c|c|c|c|}
\hline Year & $\begin{array}{c}\text { Traded Value in } \\
\text { Outright } \\
\text { Purchases and } \\
\text { Sale Market }\end{array}$ & $\begin{array}{c}\text { Traded Value in } \\
\text { Repo/Reverse } \\
\text { Repo Market }\end{array}$ & $\begin{array}{c}\text { Traded Value in } \\
\text { Interbank } \\
\text { Repo/Reverse } \\
\text { Repo Market }\end{array}$ & $\begin{array}{c}\text { Total Value } \\
\text { Traded }\end{array}$ & $\begin{array}{c}\text { Daily Average } \\
\text { Value Traded }\end{array}$ \\
\hline 1997 & 35,472 & 374,384 & - & 409,856 & 1,626 \\
\hline 1998 & 68,399 & 372,201 & - & 440,601 & 1,762 \\
\hline 1999 & 83,842 & 589,267 & - & 673,109 & 2,714 \\
\hline 2000 & 262,941 & 886,732 & - & $1,149,673$ & 4,580 \\
\hline 2001 & 37,297 & 627,244 & - & 664,541 & 2,648 \\
\hline 2002 & 67,256 & 480,725 & - & 547,982 & 2,166 \\
\hline 2003 & 144,422 & 701,545 & - & 845,967 & 3,384 \\
\hline 2004 & 262,596 & $1,090,476$ & - & $1,353,072$ & 5,369 \\
\hline 2005 & 359,371 & $1,387,221$ & - & $1,746,591$ & 6,876 \\
\hline 2006 & 270,183 & $1,770,337$ & - & $2,040,520$ & 8,130 \\
\hline 2007 & 278,873 & $1,993,283$ & - & $2,272,156$ & 9,016 \\
\hline 2008 & 239,367 & $2,274,077$ & - & $2,513,444$ & 10,014 \\
\hline 2009 & 269,977 & $1,929,031$ & - & $2,199,008$ & 8,726 \\
\hline 2010 & 297,710 & $2,010,217$ & - & $2,307,954$ & 9,232 \\
\hline 2011 & 284,090 & $1,724,382$ & 435,442 & $2,449,059$ & 8,701 \\
\hline
\end{tabular}

Source: $\underline{w w}$.ise.org

As can be seen from Table 5, the financial crisis in 2001 has hit the Bonds and Bills Market in Turkey very hard. Especially the traded value in outright purchases and sales market has fallen very dramatically at that period. Also the impacts of Global Financial Crisis in 2008 can be investigated by the fall in the traded value of repo/reverse repo market. In terms of total value of bonds and bills traded, in the year 2010 ISE was the $8^{\text {th }}$ stock exchange among the 47 stock exchanges.

Emerging Companies Market in ISE was established in August 2009. The stocks of small and mid-sized companies are being traded in this market with a different and relatively relaxed admission procedure compared to National Market. The idea behind the facilitation of the admission procedure is to provide these companies with an opportunity to raise funds through public offerings or private placements as a long term and low cost financing alternative (Report on Markets and Operations, 2010: 33). Turkish Eurobonds, international debt securities issued by the Turkish Undersecretaries of Treasury, and other international debt securities having the nature of bonds and bills registered by the Capital Markets Board and listed/registered by ISE are traded on the Foreign Securities Market. 


\section{Demutualization of ISE}

As ISE is the only stock exchange operating in Turkey, there are no competitive issues within the country to concern for the management of the stock exchange. Likewise, competitive issues outside the country are not worth to worry about because the level of electronic communication in Turkey is low compared to the other developed countries and trading in the international markets is not very common in this country context. However, this relaxed situation of ISE will not last long as the trading costs all over the world will decrease and investor information systems will develop by the improvement in the technology. Turkish Government has brought the "privatization of ISE" to the agenda in 2003. Ever since that time, privatization/demutualization of the exchange is one of the vital subjects of the government. In this section, key issues for consideration for the demutualization of ISE and the impacts of demutualization of ISE to the capital markets of Turkey is discussed briefly.

\section{Key Issues for Consideration for the Demutualization of ISE}

The Turkish economical decision makers have to consider the demutualization of ISE in details and great attention. There are two key issues falling for the consideration of the demutualization process: (1) corporate and legal structure, and (2) regulation. In the issue of corporate and legal structure, ownership issues and access rights and corporate governance are the main headlines. The economists have to decide how to transfer current interests or "seats" of members into shares and access rights to trading rights. Will they put any restrictions on ownership? Besides they have to decide whether to list the exchange or not. Board composition and representation and committees and risk management are the other crucial subjects to decide on. Should the exchange downsize the board? How many of the board members will be from members and their affiliates? Will the interest groups be presented on the board? Will there be a nonexecutive director? These decisions can be made by imitating the other exchanges demutualized and taking into account the conditions of the country's capital markets and financial structure.

Currently, ISE is a self-regulating organization, typically regulating listing, trading, market abuse and membership. There are three broad models for the regulation of the market: (1) demutualized stock exchange continues to perform all of its regulatory functions, (2) a separate entity is established by the stock exchange to perform its regulatory functions, or (3) the regulatory function is outsourced to an independent third party (Smith, 2011: 22). ISE can follow any of the models suitable for its future structure.

In the demutualization of the stock exchange, the process will be necessarily one that will be unique to ISE and the ultimate solution will be "path-dependent" and shaped by established local conditions and circumstances.

\section{The Impacts of the Demutualization of ISE to Turkish Capital Markets}

Currently, being a public corporation operating as an autonomous and professional institution, ISE is accepted as a dependable and fair market by national and international financial market players and investors. The audit, inspection and scrutiny authorities of ISE help the progress of Turkish Capital Markets. However, replacing the cooperative structure of ISE with a corporate structure would allow lots of advantages by the means of the development of the markets. Firstly, demutualization of ISE can help the stock exchange to modernize its technology and this will make a great contribution to the progress of the capital markets in Turkey. Besides, demutualization can obtain a governance structure that is more flexible in responding to industry and market conditions, avoid concentration of ownership power in a particular group of stock exchange participants and ensure financial decision-making by ensuring that resources are allocated to business initiatives and ventures that enhance shareholder value (Morsy and Rwegasira, 2010: 39). This increasing efficiency in the management of the exchange will stimulate the confidence of the investors to the capital markets. 
Demutualization can encourage ISE to obtain an initial infusion of capital and to gain easier ongoing access to capital by listing its own shares. Access to capital rising through the offer of shares is an important, but by no means dominant in the demutualization of exchanges. However, by the new funds obtained from the capital markets, ISE can invest in the trading technology and get more operational freedom. Last but not least, converting itself into a publicly-listed entity also enables ISE to undertake mergers and acquisitions to meet the growing threat of competition. On the other hand, however, demutualization can expose self-listed ISE to mergers and acquisitions threats.

Some of the academicians and professionals support the act of demutualization and selflisting of stock exchanges emphasizing the advantages of the process (Morsy and Rwegasira, 2010: 39). On the other hand, opponents of demutualization do not believe that the process may bring the expected benefits to the capital markets of the country. They think that the benefits of demutualization can also be obtained with a mutual governance structure. Additionally, they point out that forming a new financial institution is very hard considering the fragility of the investor confidence to the financial system especially in the context of emerging markets (Lee, 2002:15). Besides, the opponents argue that the new demutualized exchange will bring lots of problems: Determination of the owners of the demutualized exchange and the sources of income and the targeted services, forming the management of the exchange, developing a convenient listing and disclosure standards and forming appropriate audit and supervision commissions. In addition, developing a fair system that will constitute and strengthen the confidence of the investors is considered as one of the biggest problems. Lastly, the financial performance of the demutualized exchange is still an unsolved puzzle (Steil, 2002, and Morsy and Rwegasira, 2010: 40).

\section{Concluding Remarks}

The landscape in which stock exchanges operate has changed in the recent years with competitive pressures and threats to their monopolistic status. Most stock exchanges, until recently, have enjoyed national monopoly status with ownership rights coupled with trading rights. Increased competition among stock exchanges, alternative trading systems and improvements in telecommunication have posed a significant threat to the operating performances of the exchanges. Consequently, most of the exchanges have changed their governance structure and have become for-profit companies, opened ownership to outside investors rather than just members and introduced their companies' shares on the stock market they operate. This paper evaluates the changing ownership and governance structure of ISE and explores the challenges for ISE in the process of demutualization. The primary purpose of this study is to discuss the pros and cons of the new structure of the exchange to the financial system of Turkey and provide a recommendation whether ISE should be demutualized.

Demutualization of ISE has been brought to the agenda of Turkey in 2003 and ever since that time the Turkish Government is planning to form an appropriate organization structure, corporate governance model, business model and ownership structure for the exchange. The Turkish Financial Sector has an above the average size considering the emerging markets. However, the size of the Turkish Financial System is small and shallow compared to the developed countries. The main reasons of the limited growth of the financial sector arise from the political risks, macroeconomic policies and economic conditions. Besides, ISE could not meet the expectations such as high market capitalization, high trading volume and increase in the number of companies traded in the exchange. In my point of view, the new structure of ISE organized as a corporate entity will provide some advantages by means of the development of the financial system. Firstly, demutualization can provide a governance structure that is more flexible in responding to industry and market conditions. At this point, the critical question is whether there should be some percentage of government ownership in the structure of ISE, considering that the presence of government provides investors some kind of confidence in the markets. My position is consistent 
with Senbet and Gande (2009), stating that there should be a proper balance between two prevailing polar views: whether the government is the problem or the solution. When the pendulum shifted too far on the side of the government, there is a problem of lax regulation and fragile institutions affected easily by the financial crises. On the other hand, when the pendulum shifted too far on the side of the market, the problem is an inflexible organization in responding to the changing conditions. The problem should be sold step by step: Turkish Treasury should be one of the stockholders at the very first stage of the establishment of the new company. This will provide some reliance to the investors in the markets. However, Treasury should sell its stocks after some predetermined time; otherwise the exchange will again become a state-owned enterprise anyway.

Another advantage of demutualization of ISE could be that the new corporate structure can avoid concentration of ownership power in a particular group of stock exchange participants. The new structure of ISE will make the exchange less susceptible to Members' vested interests. Thirdly, the increasing efficiency in the management of the exchange will stimulate the confidence of the investors to the capital markets. Furthermore, demutualization of ISE can help the stock exchange to modernize its technology and this will make a great contribution to the progress of the capital markets in Turkey. Although the level of electronic communication in Turkey is low compared to the other developed countries and trading in the international markets is not very common in this country context, this does not mean that this relaxed situation will last forever as the trading costs all over the world decrease and investor information systems develop by the improvement in the technology. Besides, demutualization can encourage ISE to obtain an initial infusion of capital and to gain easier ongoing access to capital by listing its own shares. By the new funds obtained from the capital markets, ISE can invest in the trading technology and have more operational freedom. Moreover, converting itself into a publicly-listed entity also enables ISE to undertake mergers and acquisitions to meet the growing threat of competition. On the other hand, demutualization can expose self-listed ISE to mergers and acquisitions threats. I agree with the point of view of Segal (2001), Aggarwal (2002) and $\mathrm{Nu} \mathrm{Ri} \mathrm{(2011),} \mathrm{that} \mathrm{in} \mathrm{order} \mathrm{to} \mathrm{avoid} \mathrm{hostile} \mathrm{takeovers,} \mathrm{a} \mathrm{restriction}$ should be placed by the regulators on ownership by one holder or a group of holders to noncontrolling stakes of 5-10\%. However, setting a stricter barrier for foreign ownership may damage the relationship with foreign exchanges or foreign investors. Last but not least, the clarity in the formulation and allocation of regulatory responsibilities of newly formed ISE will make an essential contribution to the efficiency of Turkish Financial Markets.

There is no doubt that demutualization will resolve many of the problems faced by mutual ISE. However, there will also be some risks involved in the process of demutualization like new conflicts of interest, brokers not feeling any loyalty in the market, becoming a potential take-over target, and regulatory problems etc. Regardless of these risks and problems, I believe that the successful act of demutualization will result in many benefits to the Turkish Economy. The authorities should identify the risks and make appropriate decisions to diminish those risks in the successful process of demutualization.

In order to support the demutualization of stock exchanges, we have to provide evidence about the advantages of demutualization and strengths of the demutualized exchanges. However, demutualization is a very new subject with a recent history. Consequently, prior studies in the literature on the effects of demutualization on the financial performances of stock exchanges cover short time periods. Regarding the future line of research, financial performances of mutual and demutualized stock exchanges should be compared by using a wider range of market measures and larger sample sizes and by this way the impact of demutualization will be clearly investigated. The question of whether the demutualization of stock exchanges can have any effect to decrease the impacts of financial crises also has to be answered. Therefore, a study revealing the effects of the financial crises by making a distinction between the corporate governances of the stock exchanges would be fruitful. 


\section{Acknowledgments}

Research support from the Center for Research in Capital Markets (CRCM) (Sermaye Piyasaları Araştırma ve Uygulama Merkezi (SERPAM)), Istanbul University is gratefully acknowledged.

\section{References}

1. Aggarwal R., 2002. Demutualization and Corporate Governance of Stock Exchanges, Journal of Applied Corporate Finance, Vol. 15, No.1, pp. 105-113

2. Aggarwal R., Dahiya S., 2005. Demutualization and Public Offerings of Financial Exchanges, available online at http://faculty.msb.edu/aggarwal/exchanges.pdf, accessed on 05.09.2011, pp. $1-25$

3. Krishnamurti C., Sequeira J.M., Fangjian F., 2003. Stock Exchange Governance and Market Quality, Journal of Banking and Finance, 27, pp. 1859-1878

4. Lee R., 2002. Changing Market Structures, Demutualization and The Future of Securities Trading, available online at http://www.oecd.org/finance/financialmarkets/18450470.pdf, accessed on 23.08.2011, pp. 1-20

5. Mercan M., Reisman A., Yolalan R., Emel A.B., 2003. The Effects of Scale and Mode of Ownership On the Financial Performance of the Turkish Banking Sector: Results of a DEAbased Analysis, Socio-Economic Planning Sciences, 37, pp. 185-202

6. Morsy A., Rwegasira K., 2010. An Empirical Investigation of the Demutualization Impact on Market Performance Stock Exchanges, International Research Journal of Finance and Economics, Issue 40, pp. 38-58.

7. Nu Ri J., 2011. A Study on Demutualization of Stock Exchanges -Focusing on the Case of Korea Exchange-, available online at http://www.ksla.org/sinye_another5/1336546354-9.pdf, accessed on 20.06.2012

8. Mendiola A., O'hara M., 2003. Taking Stock in Stock Markets: The Changing Governance of Exchanges, available online at http://papers.ssrn.com/sol3/papers.cfm?abstract_id=431580, accessed on 06.07.2012, pp. 1-38.

9. Ozmucur S., 2007. Liberalization and Concentration: Case of Turkey“, The Quarterly Review of Economics and Finance, 46, pp. 762-777.

10. Segal J., 2001. Market Demutualization and Privatization: The Australian Experience, Public Documents of the XXVI ${ }^{\text {th }}$ Annual Conference of the International Organization of Securities Commissions, Stockholm, Sweden, pp. 1-11

11. Senbet L.W., Gande A., 2009. Financial Crisis and Stock Markets: Issues, Impact, and Policies, available online at http://www.rhsmith.umd.edu/faculty/lsenbet/Dubai\%20project\%20\%20financia\%20crisis-Senbet-final-09.pdf, accessed on 09.11.2011, pp. 1-35.

12. Smith H., 2011. Stock Exchange Demutualization The International Perspective, available online

http://www.cisnigeria.com/cisdocs/Papers_Presented/Workshop\%20on\%20demutualization/Sto ck\%20Exchange\%20Demutualisation.pdf, accessed on 12.08.2012, pp. 1-29.

13. Steil B., 2002. Changes in the Ownership and Governance of Securities Exchanges: Causes and Consequences, The Wharton School Financial Institutions Center, Brookings-Wharton Papers on Financial Services, pp. 1-31.

14. IMF International Financial Statistics, www.imf.org, accessed on 12.07.2012

15. IMF Global Financial Stability Report, September 2011, www.imf.org, accessed on 12.07.2012.

16. Istanbul Stock Exchange, www.ise.org, accessed on 10.06.2012

17. Istanbul Stock Exchange, Report on Markets and Operations, 2010, www.ise.org, accessed on 10.06.2012

18. World Bank, www.worldbank.org, accessed on 15.06.2012

19. World Federation of Exchanges, www.world-exchanges.org, accessed on 21.06.2012 